\title{
Framing the Mother Tac: The Racialised, Sexualised and Gendered Politics of Modern Slavery in Australia
}

\author{
P. G. Macioti ${ }^{1, *}$, Eurydice Aroney ${ }^{2}$, Calum Bennachie ${ }^{1}\left(\mathbb{D}\right.$, Anne E. Fehrenbacher ${ }^{1,3}{ }^{\circledR}$, \\ Calogero Giametta ${ }^{1,4}$, Heidi Hoefinger ${ }^{1,5,6}$, Nicola Mai ${ }^{1}$ and Jennifer Musto ${ }^{1,7}$ \\ 1 Department of Criminology and Sociology, Kingston University, London KT1 2EE, UK; \\ ofcoursecalumis@gmail.com (C.B.); afehrenbacher1@gmail.com (A.E.F.); calogiame@googlemail.com (C.G.); \\ hhoefinger@jjay.cuny.edu (H.H.); n.mai@kingston.ac.uk (N.M.); jmusto@wellesley.edu (J.M.) \\ 2 Department of Journalism, University of Technology Sydney, Ultimo, NSW 2007, Australia; \\ eurydice.aroney@uts.edu.au \\ 3 Department of Psychiatry and Biobehavioral Sciences, Semel Institute, University of California, Los Angeles, \\ CA 90024, USA \\ 4 Department of Sociology, LAMES, Aix-Marseille University, 13007 Marseille, France \\ 5 Department of Political Science, John Jay College of Criminal Justice, City University of New York, \\ New York, NY 10019, USA \\ 6 Department of Science, Berkeley College, New York, NY 10017, USA \\ 7 Department of Women's and Gender Studies, Wellesley College, Wellesley, MA 02481, USA \\ * Correspondence: pg.macioti@gmail.com
}

Received: 1 September 2020; Accepted: 23 October 2020; Published: 28 October 2020

check for updates

\begin{abstract}
Centred on the slavery trial "Crown vs. Rungnapha Kanbut" heard in Sydney, New South Wales, between 10 April and 15 May 2019, this article seeks to frame the figure of the "Mother Tac" or the "mother of contract", also called "mama tac" or "mae tac" — a term used amongst Thai migrants to describe a woman who hosts, collects debts from, and organises work for Thai migrant sex workers in their destination country. It proposes that this largely unexplored figure has come to assume a disproportionate role in the "modern slavery" approach to human trafficking, with its emphasis on absolute victims and individual offenders. The harms suffered by Kanbut's victims are put into context by referring to existing literature on women accused of trafficking; interviews with Thai migrant sex workers, including Kanbut's primary victim, and with members from the Australian Federal Police Human Trafficking Unit; and ethnographic field notes. The article unveils how constructions of both victim and offender, as well as definitions of slavery, are racialised, gendered, and sexualised and rely on the victims' subjective accounts of bounded exploitation. By documenting these and other limitations involved in a criminal justice approach, the authors reveal its shortfalls. For instance, while harsh sentences are meant as a deterrence to others, the complex and structural roots of migrant labour exploitation remain unaffected. This research finds that improved legal migration pathways, the decriminalisation of the sex industry, and improved access to information and support for migrant sex workers are key to reducing heavier forms of labour exploitation, including human trafficking, in the Australian sex industry.
\end{abstract}

Keywords: modern slavery; antitrafficking; sexual humanitarianism; Mother Tac; debt bondage; Australia; migrant sex work; bounded exploitation; sex work; sex work decriminalisation

\section{Introduction}

The definition from the Thai women was always the Mother Tac is the mother of the contract, the older female, of the same nationality as the sex workers whom they owe the debt for travel/visa and opportunity (extra manifestly excessive charge i.e., profits). The Mother Tac 
(...) controlled when they worked, ate and slept, until the debt was repaid. (Australian Federal Police case officer for "Crown vs. Rungnapha Kanbut", August 2020)

Mama tac means take the people come to sell the body. (... ) Because someone very poor need the money. Need to go another country but no money to go. Then mama tac make the visa and pay the airplane ticket for when they come here they have to work and pay money back to mama tac 50 thousand or different [it depends], if finish [paying] that all money they can leave and go, if not finish [paying] that money cannot go anywhere. (Sissi, Thai former sex worker with experience of trafficking, August 2020)

This article introduces the figure of the Mother Tac (or mae tac/mother of contract) (Theeravit et al. 2010, p. 141), a largely unexplored human element in human trafficking scholarship, inscribing her into the often racialised and gendered narrative of the figures involved in managing and facilitating the sex work of their co-nationals, such as the Laotian mama-san/mae (Molland 2010), the Nigerian madam (Mai 2016; Plambech 2017; Mancuso 2014), or the Vietnamese mother/broker (Lainez 2019, 2020).

Our aim is twofold - to highlight the way racialised, sexualised, and gendered constructions of villainism and victimhood ( $\mathrm{O}^{\prime}$ Brien 2019) in anti-trafficking and modern slavery are reproduced and constructed in Australian courts, and to point at both limits and lessons within this approach.

We build our argument drawing on qualitative interviews and fieldnotes collected in Australia between 2017 and 2020, in the realm of the European Research Council-funded research project SEXHUM, but more particularly on those produced by the two first authors during a slavery trial "Crown vs. Rungnapha Kanbut" which occurred in Sydney, NSW, between 10 April and 15 May 2019.

According to definitions under divisions 270 and 271 of the Australian Criminal Code, human trafficking encompasses a range of offences, which include crimes of slavery and servitude. The term slavery involves "exercising rights of ownership over another, including from a debt or contract" (CDPP 2019a) - the definition applied by the judge in the criminal trial in question. It is impossible to identify the true extent of slavery in Australia and elsewhere (Parliament of New South Wales 2017), and there is an acknowledged lack of research about offenders (Simmons et al. 2013), but since 2013 referrals to the Australian Federal Police demonstrate a substantial downward trend in the number of sexual exploitation cases (Lyneham et al. 2019). Our research suggests that a relative easing of access to legal work visas for migrant sex workers in Australia may have contributed to this result, particularly in NSW, where sex work is decriminalised. Within the same period, there have been very few prosecutions made in Australia under anti-trafficking laws. For instance, between 2004 and 2016, there were ten convictions for slavery and four for sexual servitude under laws applying to Commonwealth human trafficking and slavery offences. This article also refers to the term "modern slavery", for which there is no globally agreed definition, but which is used to cover a range of exploitative practices including forced labour, human trafficking, the removal of organs, child labor, and slavery-like practices. It is commonly used by advocacy groups, international organisations, and governments.

In the following sections, we detail our methodological approach and place our research within the context of existing critical scholarship on trafficking, sex work, and modern slavery, including the figures of female traffickers and trafficked victims. We aim to make sense of the complex prosecution of Rungnapha Kanbut by showing how it resulted from the interplay between the following factors: (1) racialised and gendered constructions of female villainism, (2) agentic accounts of excessive suffering and bounded exploitation (Mai 2018), and (3) a commitment to demonstrating Australia's hard line against modern slavery. By doing so, we contribute to the theoretical landscape of critical anti-trafficking scholarship, which seeks to problematise and deconstruct the way law enforcement, humanitarian interventions, and approaches to human trafficking and modern slavery are driven by anti-sex work and anti-migration agendas and focus on the prosecution of traffickers and immigration offenders rather than on the support and well-being of sex workers with experiences of trafficking and exploitation (Mai 2018; Hoefinger et al. 2020; Fehrenbacher et al. 2020). In the conclusion, we make recommendations based on our findings. Broadly, these are that the decriminalisation of the sex 
industry, as has occurred in the state of New South Wales, reduces the conditions for human trafficking as well as improving migrant workers' access to and information about legal working and migration options, and should therefore be adopted elsewhere.

For the sake of clarity, we first summarise the legal case in question as presented in court, recorded with ethnographic notes and confirmed in separate interviews with one complainant, Lia (not her real name, interview conducted in English), the Australian Federal Police case officer who led the investigation, as well as documents from the Commonwealth Director of Public Prosecutions. Both complainants for the Crown (Lia and Tilly, not their real names) gave evidence in Thai language interpreted into English by a court interpreter, as did other minor witnesses who gave evidence for the defence. No transcript from the trial was available at the time this research was published.

\subsection{Crown vs. Rungnapha Kanbut}

In August 2010, the Australian Border Force raided the premises of a council regulated Sydney brothel, looking for evidence of trafficking or immigration offences. Thirty-one-year-old Tilly was found to be working without a valid visa and was detained for immigration offences at the Villawood Immigration Detention Centre. Weeks later, and only moments before her deportation, an Australian Federal Police (AFP) case officer who led the investigation approached Tilly at the airport to ask if she had known Ms Rungnapha Kanbut, aka Rung, and if Rung had been her "Mother Tac". Tilly admitted she had lived with Rung and worked under her supervision for around five months in 2005. She said she had voluntarily repaid the debt of $\$ 45,000$ Australian dollars she owed to Rung, had not been threatened, and instead worked hard for an opportunity to earn money. The agent replied that, regardless of this reading, Tilly may have been victim of a serious crime and, if so, she could get assistance to stay in Australia if she cooperated with police. Tilly replied she did not want to get anyone in trouble and she missed her family, and proceeded to board the plane. However, months later she changed her mind and contacted the AFP through the Thai police in Bangkok, had a visa arranged, and was flown back to Sydney to assist with the investigations.

In 2007, 25-year-old Lia was also apprehended in a similar raid of a Sydney brothel. She had no identifying documents, but nevertheless co-operated fully with immigration and police. She told officials that she had come to Australia through an agent called Cheng who she had met in Bangkok, knowing that she would be working as a sex worker. He arranged and paid for her (tourist) visa and ticket but withheld them until she allowed him to photograph her naked as a guarantee she would not abscond once in Australia. On Lia's arrival in Sydney, she was told that she now owed her debt to a mae tac, Rung, who would take care of her. Lia told police how she met Rung and her husband in Sydney in 2004 and immediately went to live with them. Rung declared that the sum of the debt would be AUD $\$ 45,000$, and this amount would be deducted from Lia's earnings until the debt was repaid. She told Lia that she would only be able to keep tips from clients. Lia described how Rung pressured her to work long hours and insisted she tolerate badly behaved clients who "spat on and abused her" (CDPP 2019b), and explained how Rung's husband would drive her to many different brothels in search of work. In close to five months, Lia repaid her debt and shortly after left Rung's house and moved into flat in Sydney but continued to perform sex work as an independent contractor until the day she was detained. In this case, the police did not send Lia to Villawood but instead referred her to the Red Cross' Support for Trafficked People Programme (STPP). She agreed to collaborate with the AFP in order to pursue a trafficking case against her former Mother Tac and was therefore given a witness protection visa and subsequently a permanent residency. During the investigations, Lia told the AFP about another woman, "Tilly", who had also worked under contract with Rung.

It was not until April 2019, 15 years after the fact, that Ms Kanbut was tried in the NSW District Court for slavery offences. Following a five-and-a-half-week trial, the jury found Ms Kanbut guilty of two counts each of intentionally possessing a slave and exercising powers of ownership over a slave under division s270.3(1) of the Commonwealth Criminal Code, and dealing with the proceeds of crime greater than $\$ 10,000$ under money laundering section $400.6(1)$ of the Commonwealth Criminal Code. 
She was sentenced to eight years, two months, and 30 days of imprisonment, with a non-parole period of five years, two months, and 29 days (CDPP 2019b).

During deliberation, the jury asked a number of questions of the judge and requested clarification on the term "slavery". One of the questions was whether the accused could be found guilty only on the account of money laundry and not of slavery offences. Judge Nanette Williams instructed the jury that there could be no money laundry charges without the crime connected to them, and that, if the jury believed beyond any reasonable doubt that the two women were subjected to a debt under the circumstances described, then this would amount to slavery. In closing, Judge Williams said that Kanbut was not without compassion and had positive rehabilitation prospects but that she had kept the two women in a "prison without bars". She went on to say that a firm message was necessary because "general deterrence played an important role in sentencing for slavery offences in particular" (CDPP 2019b). Kanbut's teenage son was present in court for her conviction, along with her now ex-husband.

\subsection{Female Villains and Exploited Agents}

About half of the just over twenty convictions under Divisions 270 and 271 of the Australian Criminal Code are for female offenders (Marchant 2019). As already noted, Kanbut's major convictions were applied under s270.3(1)(a) of the Commonwealth Criminal Code, which defines slavery as the condition of a person over whom any or all of the powers attaching to the right of ownership are exercised. Division 271 contains specific offences for the trafficking of persons, including separate offences for debt bondage, although this section did not apply to Kanbut's conviction. It is now widely acknowledged that women like Kanbut form a large part of trafficking and slavery offenders worldwide (Baxter 2020a).

The figure of the female trafficker and of the madam ${ }^{1}$ has come to complicate wider gendered narratives of human trafficking into sex work as being the realm of organised crime in the hands of male traffickers, led by the demand of male clients (O'Brien 2019). Anti-prostitution campaigners who equate sex work to violence against women describe female traffickers, as "as brutal and cruel as their male counterparts" (Bindel in O'Brien 2019, p. 78). Yet, the convicted women are often former sex workers and/or victims of trafficking themselves, and research shows that, in the prosecution of these offenders, their experiences are misunderstood (Baxter 2020a). Female traffickers as well as women who organise the recruitment of sex workers and host and/or collect debts from them usually fit the category of "foreign others", as they stem from a similar class, cultural, and national background as the women who work for them. It is claimed that this allows for them to be framed more easily as villains counterposed to the figure of the (mostly) Western heroes of the anti-trafficking movement (O'Brien 2019). In effect, these female figures often assume a familial role and are referred to by the women working for them as "mothers", counterposing their villainous reputation. This has been documented amongst recruiters and madams in Laos, referred to as "mama-san/mae" (Molland 2010, p. 225); amongst Vietnamese brokers and debt collectors in Singapore, referred to as "mẹ" (Lainez 2019, p. 10); and, like Rung, amongst Thai migrant workers under debt contract as "mae tac" (Theeravit et al. 2010). While these forms of quasi-familial relations can be seen as legitimising hierarchal relationships, they can also reveal alternative, protective forms of kinship amongst sex workers and their brokers, as Lainez observed between Vietnamese migrant sex workers and their "mẹ" in Singapore (Lainez 2019) and as Hoefinger (2013) observed among "professional girlfriends" and club sex workers in Cambodia.

Complex interpersonal relationships that are not at all reducible to clear-cut definitions of trafficker and slave can indeed involve elements of care ("they look after the girls"). These relations often involve victims having to negotiate and then operate within structural constraints such as poverty, being

1 A madam is generally understood to be a negatively connotated female figure who organises and profits from the work of sex workers under her protection (Mai 2016). 
unable to speak the local language, and experiencing undocumented or illegal working status. Sex workers' decisions to "co-operate" and endure these conditions are made on the understanding that it will involve making more money than they could working in similar roles in their countries of origin, and that this will result in greater freedoms for them following the discharge of their contract (Lainez 2019; O'Connell Davidson 2015; Plambech 2017; Mai 2016). On the other hand, Molland points out how the mama-sans, recruiters of Laotian women across borders into Thailand, feel they are "helping" other women out of poverty rather than exploiting their labour (Molland 2010). Building her argument on interviews with sex workers and mama-sans, Molland concluded that it is impossible to limit the role of mama-san to that of "trafficker", as they operate in a particular social world that does not lend itself to such definition but needs to be understood in its own terms (Molland 2010, p. 25). Similarly, Lainez points at how the debt incurred by Vietnamese workers with their broker "mẹ" "can also be a profitable, non-coercive and reciprocal device for brokers and sex workers alike, a vector of 'safety' which limits some of the risks they encounter in a repressive and uncertain host environment" (Lainez 2019, p. 1).

Nicola Mai's work with Nigerian migrant sex workers who had been recruited by Nigerian "madams" (mostly workers themselves) to migrate to Paris in exchange for a debt to be repaid through sex work highlights how the relationship between workers and madams/recruiters is far from unequivocal. Mai describes the way Nigerian sex workers tolerate what they feel to be acceptable levels of constraints and "suffering" for their ultimate goal of economic emancipation and working independently, which he calls "bounded exploitation" (Mai 2016, sct. 5.3). Some workers, however, decide that they are exposed to "too much suffering", often in the case of a betrayal of the original contractual terms by the madam. This can prompt them to draw a line, break the contract, and decide to press charges of trafficking against their madams, thereby distinguishing between a level of "bounded exploitation" and "too much suffering"-i.e., "trafficking" (Mai 2016, sct. 4.1). While Lia volunteered evidence against Rung because she felt that acceptable contractual constraints had been exceeded, according to the main AFP Human Trafficking Coordination Unit case officer, Tilly's account rather served as confirmation of the conditions under which the offences took place, as she had not felt as strongly exploited as Lia. In fact, neither Lia or Tilly's cases alone would have sufficed to successfully prosecute Rung for slavery, as there needs to be more than one victim for a trafficking case to be considered worth prosecuting (i.e., likely to result in a conviction).

\subsection{Sexual Humanitarianism}

In making the claim that "mama-sans" have come to play a disproportionate role within modern slavery debates, we draw on Nicola Mai's concept of "sexual humanitarianism" (2018), which refers to the way beliefs over the vulnerability to exploitation of gendered, racialised, and sexualised subjects underpin humanitarian interventions targeting particular groups of sexual minorities, including migrant, transgender, or particularly racialised sex workers. These interventions, which include anti-trafficking raids that result in the arrest of workers under immigration offences, are justified by a humanitarian ethos which seeks to save victims, often conflating migrant sex work and trafficking or at least misjudging the extent of the phenomenon (Hoefinger et al. 2020; Mai 2018). Neo-abolitionist, anti-sex work feminist agendas aimed at eradicating prostitution, seen as per se violence against women, encourage and promote sexual humanitarian interventions and criminal and carceral solutions (Mai 2018; Musto 2016; Ward and Wylie 2017). Yet, because of a discrepancy between the actual conditions of migrant sex work and the assumed and sought for trafficking or slavery conditions, these interventions often result in the penalisation and deportation of the presumed victims (Musto 2016; Segrave et al. 2017; Mai 2018). Scholars have also highlighted the arbitrariness of the identification processes of trafficking and modern slavery victims, and the blurriness and immeasurability of definitions of modern slavery (O'Connell Davidson 2015). This has led to a focus on the alignment of successful prosecutions of specific offences and crimes, such as debt bondage (a factor in Rung's case), 
to effective deterrence, whereby the structural causes of the complex phenomena of exploitation of migrant labour that are irreducible to trafficking or modern slavery are overlooked (Segrave et al. 2017).

Unlike trafficking and slavery, which are legislated upon at a federal level, sex industry laws in Australia are determined by state and territory governments. Sex work is legal under a licensing model in Victoria and Queensland; partly legalised in the Australian Capital Territory and in Western and South Australia; and decriminalised with regulations to different degrees in New South Wales and Northern Territory. At both the federal and state level, sex worker right organisations are well-established actors in debates and policymaking on sex work (Aroney and Croft 2019; Parliament of New South Wales 2017). Neo-abolitionist, anti-sex work agendas are comparatively less influential than in other national settings where sex work is largely criminalised, such as the US, UK, or Canada (O'Brien 2017, 2019; Munro 2005; Jeffrey and Sullivan 2009). Yet, sex work neo-abolitionists in Australia claim that there are a large numbers of undetected trafficking victims in those states where legalisation and decriminalisation have been adopted and that these governance regimes only "fuel" the problem elsewhere (Project Respect 2017). These same abolitionists propose the Nordic Model of client criminalisation as an alternative (O'Brien 2017). At the same time, the "war on modern slavery" along with a proposal to introduce an Australian Modern Slavery Act (Baxter 2020b) are gradually shifting the focus from anti-trafficking to modern slavery, which widens its scope to include curbing exploitation in industries other than sex work, but are still underpinned by a focus on prosecution as a success measuring tool and of migration control as a prevention mechanism (Segrave et al. 2017, p. 182).

\section{Methodology}

This article draws on ethnographic observations and interviews with key figures involved in the month-long slavery trial of Crown vs. Rungnapha Kanbut that took place in Sydney between 11 April and 15 May 2019. Shortly following the trial, in-depth interviews were conducted with Lia, the main complainant against Kanbut, and the Australian Federal Police case officer who gave evidence for the prosecution, detailing an investigation which ran over several years. Extensive ethnographic observations were recorded by this article's principal author throughout the trial as evidence was heard from several witnesses, including Tilly—the second complainant-as well as former acquaintances of the complainants. Notes were also taken during informal contact in the field with the defence and prosecution barristers where these did not interfere with the proceedings. Rungnapha Kanbut was not interviewed, did not appear as a witness for her own defence, and remained silent throughout the trial.

Additional interviews with a view to contrasting and contextualising the observations and information gathered during the Kanbut trial were also conducted. These included a recorded interview (audio) with two highly placed officers from the Australian Federal Police Human Trafficking Coordination Unit (not directly involved in the trial). A former male NSW brothel owner acquitted of several trafficking and slavery offences in 2012 but charged for immigration offences in 2014 was also interviewed on the condition of anonymity, as were the two AFP officers. Finally, as part of her fieldwork investigating pathways for victims of trafficking, the principal author of this article followed the case of Sissi (not her real name), a former Thai sex worker with experience of trafficking and violence connected to her illegal work status. The author was able to offer her support over three years and to use her knowledge and contacts to work towards having Sissi's case re-opened and referred to the AFP, the STPP, and other relevant organisations so as to avoid her deportation and have her story heard. All the interviews and field engagement so far described were conducted in English.

While there are limits to drawing wider conclusions from a small number of interviews and ethnographic observations, this article needs to be understood as one element in a broader scholarly endeavour-a three-year long international study which investigated migrant sex workers' own accounts of experiences of trafficking and exploitation in four global settings key for migration and sex work policies: Australia (Sydney and Melbourne), France (Marseille and Paris), New Zealand (Wellington and Auckland), and the United States (Los Angeles and New York). Overall, the project, which ran between October 2016 and September 2020, gathered 245 in-depth, qualitative interviews 
(between 50 and 60 per country) with migrant sex workers with and without trafficking and/or labour exploitation experiences and about 80 interviews (20 per country) with key informant and stake holders. Informed consent was obtained from all participants, and study procedures were approved by the Institutional Review Boards of Kingston University in London and endorsed by key academic organizations and institutions in the four national settings of the project. All sex worker respondents were provided with a pseudonym to protect confidentiality.

In Australia, this article's principal author followed a methodological and ethical approach that complied with the Australian research ethical standards. P.G. Macioti conducted all fieldwork in Sydney and Melbourne with the support of several experts from the sex worker activist and Asian migrant sex worker community and conducted 60 interviews with migrant/BIPOC (Black, Indigenous, People of Colour) (47) and white Australian (2) sex workers. Interviews were conducted in English or with the use of community interpreters. Three interviews with migrant sex workers were repeated at a one-year distance to document important changes in their lives, and eight more were repeated during the current COVID-19 crisis. Over $600 \mathrm{~h}$ of ethnographic research took place in 40 different brothels and massage parlours in both Sydney and Melbourne. In response to a lack of data in this specific area, 22 interviews and over $500 \mathrm{~h}$ of ethnographic research were undertaken with Asian cis female migrant sex workers working in unauthorised and unlicensed massage parlours in Sydney and Melbourne, respectively. Key informant interviews were conducted with sex worker organisations Scarlet Alliance, SWOP NSW, and the Vixen Collective Victoria; with sexual humanitarian organisations such as Salvation Army, the Red Cross, and Project Respect; with service providers such as RhED; with the Law Firm Baker McKenzie; with Sydney City Council; and with the Human Trafficking National Coordination Unit of the Australian Federal Police.

For this article, interviews and ethnographic observations collected during and following the trial and after sentencing were compared with findings from the interviews and data collected as part of the wider research project in Australia. These were sorted and analysed using a combination of thematic analysis and the constant comparative method for the development of grounded theory, steered by the previously mentioned theory of "sexual humanitarianism", which embraces the view that assumptions about the vulnerability to exploitation of gendered, racialised, and sexualised subjects underpin humanitarian interventions targeting particular groups of sexual minorities, including migrant, transgender, or particularly racialised sex workers. Quotes were selected from the trail to illustrate and demonstrate themes related to the agency of migrant sex workers, understandings of trafficking and slavery, exploitation in the sex industry, immigration raids on sexual services premises, and the process and methods used to recruit and retain migrant sex workers in conditions that contravene their visa status but operate in a largely decriminalised sex work setting. Our aim was to illustrate the way gender, race, class, and sexuality as well as the assumption of (lack of) agency and the villainism of sex workers and third parties played out in the Rung trial. During data collection for this case study, evidence was gathered regarding the recent changes in the Australian trafficking and modern slavery scenario. Evidence was analysed to put forward arguments relating to the reasons why these changes happened.

\section{The Mother Tac}

Ms Rungnapa Kanbut was described in the trial as a 57-year-old Thai national from a lower-class rural family in the South of Thailand. Her life was acknowledged as having been difficult, and supporting character statements provided by Rung's daughter, ex-husband, other family members (2), and a neighbour described Rung as a good and compassionate person, a caring mother, and the sole parent to a (then) fourteen-year-old disabled son. When, in 2017, she returned from Thailand to care for her ex-husband Richard's elderly mother, she was apprehended at the airport for the charges (which she was unaware of) but then released on bail. For the following two years, Rung cared for her former mother in law and lived without incident in rural NSW. During the trial, Rung remained silent and did not provide any statement. She was denied bail on the grounds that she was a foreign national 
and in danger of absconding. Following Rung's conviction and as she was taken from the court, there were emotional scenes as her family and young son watched on obviously distressed, as were other observers of the trial.

While Rung was not the only actor involved in Lia and Tilly's exploitation as sex workers, she was the only one who faced charges. Judge Williams found her role to be "hands on" within an "organisation aimed to take young Thai nationals" and referred to her as the "Mother Tac". Williams explained: "she provided a home and set the conditions of work, she took their passports, she called them to check about how many clients they had. She was not without compassion and let them have limited freedoms, yet the fact the women had no English and limited resources meant they were effectively kept in a prison without bars". According to the judge, Rung's mitigating circumstances, including the character statements, as well as having no previous offences and not having re-offended over the past 15 years, meant that her sentence was kept in the mid-range of a maximum 25-year sentence: she received eight years, two months, and thirty days in prison, with a minimum of five years non-parole. In previous cases, such as Queen vs. Somsri, the latter was found to have been the "Mother Tac" of four Thai workers and was sentenced to five years for the sexual servitude of several women working in her brothel (Cameron and Schloenhardt 2012; Parliament of Australia n.d.). In Queen against Wei Tang, the defendant was sentenced to nine years for ten counts of using and possessing a slave (Parliament of Australia n.d.). Rung's eight-year long sentence which entailed two counts of possessing a slave could be seen as harsh in comparison to these when taking into account the number of victims involved.

In their 2010 study on "Understanding Recruitment Industry in Thailand", Theeavit et al. are probably the first to mention the figure of the "Mother Tac" in research, referring to Thai migrant sex workers in Bahrain:

Once they had arrived in Bahrain, they were met and controlled by a "madam" — sometimes referred to by these Thai women as their "Mae Tac" "Mother of Contract" — who would see to it that they fulfilled their work obligations per "contract". There were of course no real written contracts involved, and since they were on tourist visas, no legal work status. Their "Mae Tac" would attend to their housing and food, etc., deducting it from their earnings along with money owed to the recruiter. After all the deductions, most found that they had no money left. (Theeravit et al. 2010, p. 141)

The only other mention of Mother Tac we found in research in the English language is by Cameron and Schloenhardt, who wrote about the 2008 case of Queen vs. Somsri:

A debt of approximately $\$ 45,000$ was incurred by four Thai women in return for their 'opportunity to remain and work' as sex-workers in Australia. While in Australia, they were subject to control by a 'mother of contract' who 'exercised control over the arrangement until the debt was repaid and the girls were free to leave'. (Cameron and Schloenhardt 2012, p. 18)

The above definitions are very similar to how Tilly and Lia described their contractual and human relationship with Rung. Both women had been recruited in Thailand by a man called Cheng, who took naked pictures as a guarantee and organised visas and travel for them. Once in Australia, both were collected and housed by Rung, and Rung was the only person they ever gave money to.

Under questioning during the trial, it was put to Tilly by the defence lawyer Mr Clarke that she had no debt to Rung, and that her payment to Rung was rent, while Cheng was the actual holder of the contract. Tilly did not flinch. Rung had been her Mother Tac, the only one collecting the debt. There had been Mother Tacs in Malaysia, Singapore, and the Netherlands where she worked previously. "I would never have managed to get to work and do what I did without a Mother Tac", she said. Even Lia, who had only ever done sex work in Thailand before, was aware that Mother Tacs were "everywhere":

Mae tac is not only in Australia. Pii Cheng had a lot of countries to send me to, everywhere they have mae tac, it is because I said Australia-to see Kangaroos!- that I was sent to pii Rung. (Lia, August 2020) 
When asked about what they know about "mae tacs", other Thai respondents in our research sample also gave similar definitions. Lia, however, acknowledged that each case is different:

You don't know what is going to happen to you, if you are in bad luck or not bad luck, bad luck is if you are caught by immigration or if you have a bad mama who hits you, or you are not pretty and don't make money, pii Rung never did that ( . . ) I still feel bad about pii Rung in prison, but I had to do what I had to do. (Lia, August 2020)

Lia did not remember ever calling Rung "mae", as she was sharing the house with Rung's real teenage daughter and toddler son, but instead called her "pii" Rung, and explained to us that "pii" denotes a form of respect towards an older person, a sister, or an "aunty". While she felt exploited by Rung, Lia was critical of the sentence and insisted in her interviews with us that, although she felt trapped by Rung, she was not physically abused.

I feel sorry for her, she lost weight, she feels guilty, I'm sorry, I was very close to her daughter (... ) I don't know if it is correct, I feel sad already, she already hurt me, I don't need her to go jail, it is done, it is not going to change what she has done to me, I cannot turn back. (...) she didn't hit me or anything like that she just sent me to work, she just pushed me to work, ( ... ) she didn't hurt me from the body, and I understand her too. (Lia, September 2019)

Tilly, on the other hand, gave evidence that she had known the work conditions would be gruelling, while insisting that she nevertheless was willing to work. She did not feel pushed and was glad for the opportunity to earn money.

Without doubt, the complexity and ambivalences of cases of exploitation in quasi-familial respect relations of subordination such as Lia's and Tilly's should not diminish or devalue the harms they endured. However, in cases like Rung's, where even the victims find the ruling too harsh, the question arises of what prompts such a severe sentence. We suggest that it depends on the interplay between several factors, including the Mother Tac's racialisation as "other", her gender, her class, the demonisation and strict construction of the figure of the "facilitator" as a trafficker, and the inherent harm attributed to sex work as opposed to other work.

In her recent monograph on the villains, victims, and heroes of anti-trafficking, Erin O’Brien (2019) illustrates that "foreign figures" are the most commonly acknowledged villains in trafficking narratives. Constructing foreign influences as "evil" helps to frame Western responses as "heroic". On the other hand, while the figure of the woman trafficker seemingly disrupts gender norms of trafficking as a male domain, it also evokes a sentiment of revulsion for those who have betrayed their own gender (O'Brien 2019, p. 78). The betrayal of one's own gender is worsened when offenders have been victims themselves, as Baxter points out in her research on six convicted Asian female traffickers (and previous victims) in Australia. In sentencing, rather than acknowledging past experiences as mitigating circumstances, some judges commented: "she should have known better" (2020a, p. 7). Baxter (2020a) explores this further by showing how the Australian criminal justice system, in emphasising a "victim" and "villain" approach, fails to acknowledge social structural and gendered constraints in the sentencing of female traffickers (Baxter 2020a, p. 2).

White Australian male partners involved in the exploitation of migrant sex workers in several slavery cases in Australia (including Queen vs. Wei Tang, Somsri, and Tanuchit) received more lenient sentences than their spouses (Parliament of Australia n.d.). This was also the case here. Rung's husband Richard did not face charges, although he was responsible for the transport of the women to and from work. On the other hand, gender also intersects with class, as Seal (not his real name), a cis male Cambodian-born former brothel owner accused of trafficking three Thai women into sex work in 2012 and acquitted in 2014, pointed out. In his interview with us, he insisted that, unlike Rung, he could afford $\$ 500,000$ for bail, and was in a position to fund an appeal. He stressed the psychological damage he had suffered due to the criminal case against him:

In the Australian Court of Law, you should be innocent until proven guilty. In the case of [sex] trafficking, you are guilty until proven innocent. (Seal, November 2019) 
Seal's felt injustice is not surprising. Decades of neo-abolitionist campaigns and moral panics around the extent of sex trafficking and the inherent exploitation and violence of all sexual labour, together with dominant representations of particularly racialised and gendered groups of migrant sex workers as passive victims (Mai et al. 2020), all converge in constructing facilitators of the sex work of others as necessarily guilty, evil traffickers, as opposed to their innocent victims.

Despite acknowledging that sex work is a legal occupation in Australia, in sentencing Judge William noted that Rung took advantage of the women's lack of English, told them not to run away, and called them at work to ask about how many clients they had seen. Williams called these clear signs of control and enslavement which "robbed them of their body" and pointed at the inhumanity "for someone to be denied the freedom to decide with whom to have sex". By framing sexual exploitation in this way, Mother Tacs are found to be lacking humanity and are denied any chance of redemption because of the sexual nature of the exploitation. While we do not doubt that Rung harshly exploited Lia and Tilly by expecting and pushing them to work exceedingly long hours to pay back an unreasonable amount of debt that went far beyond the cost of bringing them to Australia, hosting their accommodation, and taking the profit margin into account, our analysis of her sentencing points at how dominant assumptions around gender, race, class, and sexual labour intersect in the construction of the Mother Tac, leading to a villainous conclusion. Instead, our argument suggests that the Mother Tac is more ambiguous, should be seen as socially contingent, and should not be reduced to the role of unambiguous "trafficker", as with other female figures involved in the organisation, recruitment, and facilitation of the sex work of others (Molland 2010; Lainez 2019; Mai 2016).

\section{Agentic Exploited Workers vs. Consenting Slaves}

Twenty-four-year-old "Tilly" had worked in the sex industry for approximately five years before arriving in Australia in March 2005. She came from a middle-class family, but when her father's business went bankrupt she dropped out of higher education and migrated to undertake sex work abroad. She made use of agents and other "Mother Tacs" to work in Malaysia, Singapore, and the Netherlands, but was prevented from entering the UK and, after being deported back to Thailand, decided to pursue a trip to Australia. She was introduced to Cheng and he organised her (tourist) visa and travel. Cheng insisted that he photograph her naked as a guarantee that she honour her debt and deposited money into her bank account so that immigration would accept her on a tourist visa. Tilly was collected at Sydney airport by an unknown driver and taken to a hotel where she was appraised for her suitability. A day later, Rung and her husband Richard drove Tilly to their home. Rung then laid out the debt amount and conditions. Tilly had expected a bond but, having just arrived in the country, she had little idea of how much it would be and how many clients she needed to see in order to repay it. She knew her visa did not allow her to work and was aware of the risk of deportation. She was given clothes, shoes, condoms, lube, a key to the back entrance of the house, and a phone-card to call her mother. Each day, Richard would drive her to one of several different brothels and, on her return, she would give her earnings to Rung. She was able to keep client tips, which amounted to around $\$ 100$ per week. She was told that hard work would see her repay the $\$ 45,000$ debt in approximately four-five months, but she chose to add an extra $\$ 1000$ per month to this amount to be sent to her family. Her passport was taken as collateral on the understanding that it would be returned when she repaid in full. She was allowed one day a week off work but rarely took it, and was not pushed to work during her menstrual period. Tilly's earnings were $\$ 400 / \$ 500$ per day, which allowed her to repay the debt in the expected time. She then left Rung's to live with a friend and continued to perform sex work without the pressure of the debt, choosing where and when she worked, until the immigration raid five years later. While at Rung's, she lived with two other women in similar circumstances, including Lia.

Lia was raised by her grandmother and aunt in rural Thailand. Her mother passed away when she was nine and she met her father once as a teenager. The family had little money. After leaving school at 14, Lia worked in hospitality and at bars and started working in the Bangkok sex industry at 
the age of 20. When she was 22, a friendly colleague said she was going abroad to work, suggested that Lia do the same, and introduced her to Cheng. Australia was their preferred destination. When Lia landed in December 2004, she went straight to Rung's, where the conditions of the debt were explained. These mirrored Tilly's description. However, in Lia's case the conditions proved more onerous because she was less practised in sex work than Tilly, and for her the number of clients and working conditions were much more demanding than what she had experienced in Bangkok, where she had seen a maximum of two or three clients a day in contrast to an average of ten clients a day in Sydney. Her colleague from Thailand was also living at Rung's, and while both women worked Rung did not pressure Lia to work more than she was willing to. Then, a month later her friend was apprehended in a brothel immigration raid and deported. As she had not finished repaying her debt, Rung's income was suddenly decreased. Lia had become the only source of income for Rung, who started pressuring her to work harder, even during her menstrual periods. Rung threatened that if Lia absconded, she would be found and be made to pay. Eventually, Lia finished repaying her debt and stayed at Rung's for a few more months, paying \$200 per week in rent, until she was evicted by Rung following an argument. Lia went to live with a client who then became her boyfriend and continued working in the indoor Sydney sex industry without a valid visa until she was apprehended in a raid in 2007.

The two women's stories bear similarities and differences. For both, the main goal was to migrate for a better life, and they both endured four to five months of "bounded exploitation" to achieve it. Once in Australia, their goal was to repay their debt as quickly as possible and start earning money on their own, without being apprehended by immigration, for as long as was possible. They realised that, by working illegally, any complaint to the police would mean possible deportation-and the end of their migratory project. As Lia noted, "bad luck is if you are caught by immigration".

Tilly's experience of bounded exploitation under Rung's control was less troubled than Lia's, and as a consequence when she approached by the AFP at Sydney airport, she defended Rung. Rung had "looked after her", Tilly "did not want to get anyone in trouble", and she "wanted to go home". Even after changing her mind and agreeing to give evidence against Rung two years later, she would not agree to give a victim impact statement. Lia, on the other hand, still felt resentful about her experience with Rung, and on the very day of the raid took the opportunity to report what she had suffered.

I didn't go to police myself ( . . ) when immigration caught me, I thought I am going to say all the truth. I don't care if they send me back. I thought Stefano [her boyfriend at the time] would take me back here. ( . . ) I had no choice and not a reason to lie. I had already paid my debt. I told them my story and they thought it is a good story and they sent me straight to the police. ( . . ) I was happy cause I knew I was going to stay in Australia. They said I have to go to court; it will take time. I knew I was going to stay here, cause they sent me home after!! (Lia, September 2019)

When Rung's trial was first reported, tabloid media picked up on the defence's argument that Lia and Tilly were not to be trusted. They were experienced sex workers who lied to Australian immigration and were only testifying now because of their desire for permanent residency: "Thai sex worker who came to Australia to work illegally was granted a permanent visa, assisted with accommodation and helped to set up a bank account in exchange for giving evidence against a woman accused of enslaving her" (Crawford 2019). The suggestion was that Lia's testimony was questionable and given with a permanent visa in view.

During the trial, Lia and Tilly's consent to migrate, engage in sex work, and repay the debt was also framed to be at odds with scripted definitions of "real slaves". According to Rung's defence counsel, Mr Clarke, the whole case was "a-washed with consent". Instead, for the prosecution the victims' consent to the slavery-like conditions was to be found irrelevant in the determination of whether they had been enslaved, a definition which was then accepted by the judge. We suggest that both positions, the one focussing on the women's consent and the one disregarding it completely, are a symptom 
and consequence of the same problem with contemporary modern slavery, with its focus on extreme forms of exploitation that are ultimately irreconcilable with migrants' agency within constraints and miss tackling the causes and actual experiences of the exploitation they endure (Andrijasevic 2010; O'Connell Davidson 2006; Mai 2016). The denial of migrants' agency is at the core of the way sexual humanitarian and modern slavery-centred approaches pretend to fix the problem by focussing on the prosecution and criminalisation of extreme cases of "modern slavery", rather than addressing the much wider phenomena of migrant labour exploitation, which are impossible to understand as such. Understanding migrant workers as agents who seek to migrate under limited options and whose very agency is constituted by their experiences of bounded exploitation (Mai 2016) would help us move beyond misleading and short-sighted dichotomies between the deceptive undocumented migrant (as the defence tried to frame Lia and Tilly) and the real victim (which Lia and Tilly were ultimately found to be).

Lia's experience is paramount to understanding agency within bounded exploitation as the subjectively felt, agentic process through which she drew the line and began defining her experiences as exploitative:

When they [immigration] took my friend, she [Rung] started to push me and not give me any day off ( . . ) not even when I had my period I could rest. I worked from 10 to 10, sometimes I was not busy, but sometimes I had to work two shifts in a row. (... ) She pushed me too much, I needed sleep and she said go to work, you are lazy, but I was crying. (Lia, September 2019)

Her account challenges binary ideas of fully consenting agents or "real slaves". It was indeed "too much", the line that Rung crossed when she started pushing Lia to work harder, that prompted Lia to tell the AFP all about her story when she was apprehended and then to go ahead with giving evidence, assisting with the investigations, and giving a victim impact statement. The bounded exploitation Lia had endured in the first month working under the contract for Rung and the one Tilly embraced during the full length of her contract had become what Mai's research defines as "too much suffering" (Mai 2016, sct. 4.1). It was the crossing of this line that eventually made Lia herself understand her experience in terms of trafficking and exploitation, yet also reclaim her agency:

[Trafficking] is a bad thing for working girls. Forcing girls to come to do sex work ( ... ). I think for me it was the same, I just had no real shackles, but she knew how to talk well, she used words well ... She pushed me too much. ( ... ) Exploitation is being pushed to work. What Rung did to me $100 \%$. ( ... )

Once I said to Rung I will go to police if you push me to work again. I told her really strong. She was scared then. She had to let me stay and sleep. ( ... ) I am strong but pii Rung didn't hit me or anything 'cause she knew if she does I will run. (Lia, September 2019)

Lia's description of how she defended herself against continued pressure from Rung shows the limits of clear-cut, binary understandings of forced and free labour, of innocent victim and agentic migrant worker. The very constraints and bounded exploitation under which Lia migrated, stayed under the control of Rung, and went ahead with testifying against her define her as an agent and are rooted in her own definition of exploitation, in stark contrast to the effacement of agency through regarding consent as irrelevant in modern slavery cases. Crucially, Lia's definition of her condition as "too much suffering", which went beyond the debt and was experienced as exploitation, was likely the necessary factor that determined the very possibility of prosecuting Rung. The prosecution and judge were clear in their submissions and statements that Lia was the main victim, the one who best described slavery-like conditions, while Tilly's account confirmed Lia's story and so strengthened the prosecution case. Had the two stories been like Tilly's-i.e., lacking Lia's sharp insistence that Rung's treatment was an abuse of the contract - the trial may have lacked the evidence needed for slavery conviction. This shows the centrality of Lia's agency and, at the same time, the arbitrary line that can determine what is understood as slavery or not. 


\section{The Disappearance of the Mother Tac-Lessons from Australia}

Under division 270 and 271 of the Australian Criminal Code, which legislates trafficking and slavery-related offences, slavery indicates "the condition of a person over whom any or all of the powers attaching to the right of ownership are exercised" and is punishable for up to 25 years of imprisonment (Department of Home Affairs of the Australian Government n.d.). Drawing a line between slavery and harsh labour exploitation has been recognised by several prosecutors, judges, and defence representatives in previous Australian case law as being exceedingly complex. For instance, during the case against Wei Tang, High Court Judge Michael Kirby insisted on the necessity of properly defining slavery-otherwise, "lots of harsh employment contracts are going to slip over into slavery and are going to be prosecuted with a potential of 25 years imprisonment" (McInnes and Wilson 2012, p. 64). During the trial against Rung, it took two full days of debate between the Crown, Mr Clarke, and Judge Williams for the latter to produce directions and a slavery definition for the jury. When doing so, Williams noted the difficulty of defining slavery at a time in history when it is an outlawed practice. She then instructed the jury that, although businesses often involved debts and contracts, these things on their own do not indicate slavery, and that the jury had to distinguish between slavery, which is power of ownership, and harsh employment-yet harsh employment was not defined further. She continued by stating that it was completely up to them to do so by considering several elements-the nature and extent of the work, the restriction of freedom of movement, the amount of control and consent, and the inadequacy of payment. The jury deliberated for over one week, asking several clarification questions and losing one member who was obliged to travel overseas, and a second who could not agree with the decision of the other jurors on (undisclosed) religious grounds. The ten jurors left came to a verdict of slavery.

The difficulty in producing a definition of slavery indicates the limits of the concept of "modern slavery" for the purpose of tackling migrant labour exploitation-which are confirmed by the lack of definition of what "harsh employment" is. According to the AFP officer who followed Rung's case since its beginning, many cases do not get to be taken on by prosecution for lack of evidence, as they would see them as too likely to fail, confirming what previous research has established about trafficking and slavery cases in Australia (Segrave et al. 2017, p. 62). In fact, since the adoption of divisions 270 and 271 in 1995, there have been only 21 cases of successful convictions of trafficking and modern slavery-related offences in Australia, of which 18 related to sexual exploitation, while 841 cases have been referred to the AFP, 508 of which involve sexual exploitation (Lyneham et al. 2019).

Despite the low numbers, Segrave et al.'s research in Australia highlighted how prosecution has become the very gauge of justice, with convictions of offenders being upheld as evidence of success and progress in efforts to combat exploitation and slavery (Segrave et al. 2017, p. 115). Crucially, the authors found that convictions were believed to be the best deterrents across different state and civil society actors in the Australian anti-trafficking and modern slavery fields, yet they did not find any evidence to demonstrate that effect (Segrave et al. 2017, p. 183). Judge Williams was clear about her reason for Rung's sentence despite her good chances of rehabilitation and her good records-sending a strong message to organisers and recruiters that Australia would not condone such an "insidious trade" and that "any society which fails to denounce slavery is gravely diminished" (CDPP 2019b). The moral message about showing Australia's strong anti-slavery values (sic) and functioning as a deterrent for other criminals who may be involved in slavery was therefore key to Williams' sentence.

While it is beyond the scope of this article to prove whether convictions have any effect on the actual occurrence of trafficking or modern slavery cases, our research data show that, generally, a punitive, criminal approach does not address the causes of the problem and is therefore unlikely to drastically reduce it on its own. When Wei Tang was tried for slavery in 2008, sex worker advocate Dr Elena Jeffreys commented: "Prosecutions are not indicators of success. They are the result of a short-sighted failure to understand the issue" (the issue being the manyfold forms of labour exploitation that migrant workers endure because of their lack of access to labour rights) (Kissane 2008). Jeffreys went on to suggest that the main way to improve the working conditions of Asian migrant sex workers in 
Australia was to provide them with appropriate work visas (Jeffreys 2008). So, what has changed since, and why?

Rung's slavery crimes while acting as a Mother Tac date back to 2005. According to the data $\mathrm{X}$ gathered in Australia, debt bondage for sex workers is a far less common phenomenon today. Official statistics (Lyneham et al. 2019) convene with SEXHUM's data: over the past 15 years, there has been a gradual yet overall drastic decrease in referrals, cases, and prosecutions of trafficking, slavery, and debt bondage in the Australian sex industry. Between 2014 and 2017, referrals for sexual exploitation went from 31\% to $11 \%$ of all cases (Lyneham et al. 2019, p. 2). According to the Australian Federal Police Human Trafficking National Coordination, the "modern slavery" scenario has "changed exponentially":

15 years ago, referrals were predominantly sexual servitude. ( ... ) There are less intelligence reports coming through than we historically received. We're not even hearing whispers, previously we would have clients who have visited certain brothels report "I saw a girl last night", and, "I am concerned about her or the conditions she works in"; we're not even really getting these reports as we were in the past.

(AFP Human Trafficking Coordination Unit, May 2019)

As of November 2019, referrals for sexual exploitation to the Support for Trafficked People Programme were 30\% of all referrals, as opposed to 100\% in 2012 (Red Cross 2019). Between July 2019 and April 2020, the Red Cross had three new referrals for sexual exploitation and, as of 4 May 2020, was supporting a total of 13 clients, most carried over from previous years. Amongst the 47 migrant sex workers we interviewed, the vast majority (43) of whom were currently on student, partner, permanent, or bridging visas which allowed them to legally work in Australia, only two had experienced trafficking-like conditions over or about a decade ago, whereas most had endured other forms of labour exploitation-such as unsupportive and pushy managers or clients, or too high shares to pay to the house. Yet, alongside this most reported feeling less exploited by the sex industry than other industries they worked in, such as hospitality. Those who knew or had heard about instances of trafficking, debt bondage, and particularly "Mother Tacs" said it is was a thing of the past, which was confirmed by the AFP.

That was before. It's become too hard. Mama tacs I know have gone back to Thailand now. (Linda, Thai migrant sex worker, August 2020)

When asked about the reason for the shift, the AFP case officer in Rung's case and the representatives of the AFP Human Trafficking Coordination agreed it was a combination of several factors but primarily the increased opportunities for migrant sex workers to access legal visas, such as student and working holiday visas, and to legally migrate and work independently in the Australian sex industry. Between 2008 and 2015, the Australian government introduced a series of changes in their immigration policy that increasingly lowered the threshold for many migrant workers, particularly from countries such as Thailand and China, to access student visas that would give them the right to work $20 \mathrm{~h}$ per week (Spinks 2016), while other countries such as South Korea could access working holiday visas (Jung and Jung 2020).

I think the main reason is that they don't need to do illegal things to come and work here in the industry, whereas back then, they didn't have those visa options, and now, I think it's far more palatable to come out here and work legitimately and of their own free will and choice. (... ) A student visa and working holiday visas allow them to work legitimately in the brothels without fear of deportation. (AFP Human Trafficking case officer in Rung's case, March 2020)

The other factors mentioned, apart from the role of successful convictions as a deterrent, were seen as linked to this change in immigration policies. These included a change in the modus operandi of brokers and agents. Who now communicate directly with workers in the organisation of student visas. Our findings confirm that most migrant sex workers from Asian countries migrated using 
agents who had organised a student visa for them for sums ranging between $\$ 500$ and $\$ 3000$. Another important factor mentioned by the AFP and confirmed by our data was an increased use of information technology and social networking amongst migrant sex workers to exchange knowledge about safe and legal pathways to sex work and migration in Australia:

They're far more, for want of a better terms, savvy and independent and far more knowledgeable, the generation now; I know it's only 10 years, but they're far more technologically-savvy, they're far more worldly, coming to a new country, they're able to get visas to work. (AFP Human Trafficking case officer in Rung's case, March 2020)

People are coming in on student visas and they've got their mobile phones and they can access the internet, so it's a different time than what it was 15 years ago when we were seeing it at its peak. (...)

And they're not embarrassed ... when you say it's not an offence to do sex work in New South Wales ... they're like, "Oh yeah". (AFP Human Trafficking Coordination Unit, May 2019)

Indeed, both SEXHUM data and the AFP representatives interviewed concur that the possibility of being able to work with valid visas and in a decriminalised environment such as the state of New South Wales ${ }^{2}$ has a positive influence on the degree of independence that sex workers can achieve from exploitative managers and operators. This is because an increased availability of more (legal) work options within the industry promotes access to justice, while decriminalisation decreases the stigma attached to sex work to some extent (Mai et al. 2020):

[Decriminalisation] reduces the stigma in relation to the actual occupation, and any issues for them to report [crimes]. (AFP Human Trafficking case officer in Rung's case, March 2020)

It's only New South Wales and New Zealand that have adopted and sustained the decriminalised model for a period of time, and that [curbing exploitation] was one of the intentions of decriminalisation. They are the only two places in the world that have it and have sustained it. So, it [the reduced cases of sexual exploitation] could be partly an outcome of adopting something that does give people a choice and give them some power, decriminalisation. (AFP Human Trafficking Coordination Unit, May 2019)

In November 2019, the Northern Territory government passed a sex work decriminalisation bill, drawing on lessons learnt from existing decriminalisation bills and their regulatory policies in New Zealand and NSW (Roberts and Breen 2019). Sex work decriminalisation as a legislative model has been already widely argued to be the best available legislative framework for accessing rights, health, justice, and protection for all sex workers (Amnesty International 2016; Selvey et al. 2018). Our findings complement and add to this evidence by arguing that the Australian case exposes how a combination of decriminalisation of sex work and increased legal migration options are key to decreasing cases of trafficking, slavery, and migrant sex workers' general labour exploitation.

We cannot empirically exclude the possible influence of elements of deterrence in the lowering of the numbers of cases of trafficking and slavery in the Australian sex industry. However, our data strongly suggest that the latter is much rather a consequence of migrants' improved access to legal,

2 In 1995, New South Wales removed most aspects of adult sex work-related offences, making sex service premises a legal land use, to be regulated through environmental planning instruments rather than through the application of criminal law. Street work is allowed only in defined areas, far from churches or dwellings. Even if, to the best of our knowledge, they have not been used since the 1995 Law Reform, S16 and S15 of the Summary Offences Act-which criminalise, respectively, soliciting within massage parlours and living on the earnings of a prostitute-were never repealed. Councils have threatened to use S16 again against unauthorised erotic massage businesses. Local councils became the regulatory body for sex establishments, which need to acquire a DA (developmental building authorisation) from them to be authorised to provide sexual services. 
decriminalised pathways to migration and sex work, accompanied by increased networking and information-sharing on work rights and opportunities among migrant sex workers themselves, which then resulted in a shift in the modus operandi of agents and brokers, including the disappearance of the figure of the mama tac in Australia. This does not mean that the labour exploitation of migrant sex workers has disappeared. The AFP coordination officers spoke about the challenges in identifying the means for detection under these new conditions. Moreover, they reported that the largest barrier in the identification of victims is their continued lack of trust in and reluctance to speak with the police. The AFP Human Trafficking Coordination Unit also acknowledged that police could not simply depend on search warrants (i.e. raids) as a means to access possible victims.

As we have highlighted elsewhere (Mai et al. 2020), sexual humanitarian, racialised discourses on Asian migrant sex workers as exploited victims are carried on in Australia by the media and by neo-abolitionist organisations (Sodsai 2019; Project Respect 2017), who welcome raids and compliance visits in the name of curbing trafficking and sex work exploitation. Depending on the state or territory, these raids concentrate on the unauthorised, unregulated, criminalised, or unlicensed sectors, and within these, on majority Asian-run and staffed venues (Mitchell, 2019). As a consequence, deportations of migrant sex workers are still happening in Australia, particularly in states and territories where sex work is not decriminalised, as they commit a criminal offence if they are caught working in illegalised sections of the industry even when holding a valid visa (Renshaw et al. 2015). This repressive approach points at the strength of the legacy of sexual humanitarian moral panics about the extent of trafficking and exploitation in sex work that is not at all confirmed by evidence.

\section{Conclusions}

The principal aim of this article was to investigate how the figures of the "Mother Tac" and her "victims" were constructed in the Rung trial. We placed these figures within gendered and racialised narratives that assume migrant sex workers with trafficking experience as lacking agency and constrain their access to justice and support commensurate to the range of unfair and exploitative labour conditions that persist even in a decriminalised sex work legal framework. We also highlighted how a "modern slavery" approach to trafficking, which relies heavily on the victim's subjective accounts of bounded exploitation and on harsh sentences for the perpetuators, obscures attention to alternative structural reforms, such as increasing the number of legal pathways for migrant sex workers to participate in a decriminalised sex industry.

It would be wrong to think that because Australia has prosecuted relatively few cases of modern slavery the influence of this approach is on the wane. As we write, Australia is conducting a consultation on its 2020-2024 National Action Plan to Combat Modern Slavery, and in New South Wales a petition is being put forward to bring the NSW Modern Slavery Act into force (Parliament of New South Wales 2020). In the submission SEXHUM provided to the Australian Government, the authors insist on the importance of learning from Australia's progress in reducing trafficking and slavery in the sex industry and on applying those lessons to further curb migrant labour exploitation in sex work as well as in other industries. This includes focussing on improving migrants access to legal migration paths, work visas, and work options and fully decriminalising the sex industry in all states and territories, rather than priming the criminal justice system to prosecute a symbolic number of modern slavery cases and curb immigration offences. Our research in Australia has indeed confirmed what critical anti-trafficking scholars have already amply argued: framing migrant sex workers' exploitation in terms of human trafficking and modern slavery, rather than understanding them as agents with limited access to legal paths to migration and labour, leads to their very exploitation being largely left unaddressed, hiding the structural roles of border regimes, unequal opportunities, and exploitative labour relations (O'Connell Davidson 2015; Segrave et al. 2017). Moreover, the decriminalisation of sex work and migration, contrary to purely criminal justice approaches, tackles exploitation at its root causes-poverty and the lack of legal migration and work options. Our research data show that addressing labour exploitation by providing improved labour rights is a more adequate 
response than failing to prosecute exploiters under legal concepts that are difficult to define; only tackle a very small number of cases; are often disproportionate; and rest on short-sighted and fixed racialised, gendered, and sexualised constructions of villainism and victimhood, of which the Mother Tac serves as one example. In stressing the need to tackle migrant labour exploitation beyond the narrow legal definitions of trafficking and modern slavery, we call for the development of better working definitions of migrant labour exploitation for policymaking, which this research has only started to address.

Unfortunately, despite important advancements in the decriminalisation of the sex industry in New South Wales and recently in the Northern Territory, Asian migrant sex workers in Australia are still associated with victimhood linked to cultural attributes and to the nature of sex work, leading to continued sexual humanitarian interventions which can result in deportations and traumatising experiences for migrant sex workers (Mai et al. 2020). In order to further improve the working and living conditions of migrant sex workers and people with trafficking experience in Australia and worldwide, there is an urgent need to improve access to legal migration pathways, implement the full decriminalisation of sex work, and defy sexual humanitarian framings and interventions based on moral and racialised assumptions of the victimhood of migrant sex workers. In order to counterbalance neo-abolitionist, sexual humanitarian discourses not based on evidence, we call for more research into whether and how the decriminalisation of sex work and migration would decrease the incidence of the trafficking and migrant labour exploitation of sex workers.

Author Contributions: P.G.M. wrote the first full draft of this article, co-wrote its revision and conducted all interviews, fieldwork, data analysis and coding for it; E.A. edited and co-wrote the article and its revisions and participated in most fieldwork and interviews related to the trial; C.B., A.E.F., C.G., H.H., N.M. and J.M. equally contributed to the theoretical and methodological framing of the article and edited its final version; N.M. led the SEXHUM project and secured all funding for it. All authors have read and agreed to the published version of the manuscript.

Funding: This research was funded by the European Research Council.

Conflicts of Interest: The authors declare no conflict of interest.

\section{References}

Amnesty International. 2016. Policy on State Obligations to Respect, Protect and Fulfil the Human Rights If Sex Workers. Available online: https://www.amnesty.org/en/documents/pol30/4062/2016/en/ (accessed on 31 August 2020).

Andrijasevic, Rutvica. 2010. Migration, Agency and Citizenship in Sex Trafficking. London: Springer.

Aroney, Eurydice, and Penny Croft. 2019. How Sex Worker Activism Influenced the Decriminalisation of Sex Work in NSW, Australia. International Journal for Crime, Justice and Social Democracy 8: 50. [CrossRef]

Baxter, Alexandra. 2020a. When the line between victimization and criminalization blurs: the victim-offender overlap observed in female offenders in cases of trafficking in persons for sexual exploitation in Australia. Journal of Human Trafficking 6: 327-38.

Baxter, Alexandra. 2020b. Forced Labour, Sexual Exploitation and Forced Marriage: Modern Slavery in Australia Hides in Plain Sight. The Conversation. Available online: https:/theconversation.com/forced-labour-sexual-exploitation-andforced-marriage-modern-slavery-in-australia-hides-in-plain-sight-140838 (accessed on 31 August 2020).

Cameron, Matthew, and Andreas Schloenhardt. 2012. Punishing trafficking in persons: International standards and Australian experiences. Bond Law Review 1: 1-29.

CDPP. 2019a. 'Crimes We Prosecute' Human Trafficking and Slavery.'. Available online: http://www.cdpp.gov.au/ crimes-we-prosecute/human-trafficking-and-slavery (accessed on 10 October 2020).

CDPP. 2019b. Prosecuting an "Insidious Trade" Woman Who Helped Force Thai Women into Sex Slavery Jailed. Available online: https://www.cdpp.gov.au/case-reports/prosecuting-〈T1\textquoteleftinsidious-trade\T1〉 textquoteright-woman-who-helped-force-thai-women-sex-slavery-jailed (accessed on 31 August 2020).

Crawford, Sarah. 2019. AFP Helped Sex Worker Get Visa, Daily Telegraph/Sunday Telegraph/Sunday Style Magazine. April 16. Available online: https:/www.dailytelegraph.com.au/news/nsw/afp-helped-thai-sexworker-get-visa-ahead-of-slavery-trial-trial-told/news-story/8f6922c43b9c3513edb68da499bfe4d3 (accessed on 31 August 2020). 
Davidson, Julia O'Connell. 2006. Will the real sex slave please stand up? Feminist Review 83: 4-22. [CrossRef]

Davidson, Julia O'Connell. 2015. Modern Slavery: The Margins of Freedom. London: Springer.

Department of Home Affairs of the Australian Government. n.d. Criminalising Human Trafficking. Available online: https://www.homeaffairs.gov.au/about-us/our-portfolios/criminal-justice/people-smuggling-humantrafficking/human-trafficking (accessed on 31 August 2020).

Fehrenbacher, Anne E., Jennifer Musto, Heidi Hoefinger, Nicola Mai, P. G. Macioti, Calogero Giametta, and Calum Bennachie. 2020. Transgender people and human trafficking: intersectional exclusion of transgender migrants and people of color from anti-trafficking protection in the United States. Journal of Human Trafficking 6: 182-94.

Hoefinger, Heidi, Jennifer Musto, P. G. Macioti, Anne E. Fehrenbacher, Nicola Mai, Calum Bennachie, and Calogero Giametta. 2020. Community-based responses to negative health impacts of sexual humanitarian anti-trafficking policies and the criminalization of sex work and migration in the US. Social Sciences 9: 1. [CrossRef]

Hoefinger, Heidi. 2013. Sex, Love and Money in Cambodia: Professional Girlfriends and Transactional Relationships. London: Routledge.

Jeffrey, Leslie Ann, and Barbara Sullivan. 2009. Canadian sex work policy for the 21st century: Enhancing rights and safety, lessons from Australia. Canadian Political Science Review 3: 57-76.

Jeffreys, Elena. 2008. Truth and Visas Will Set Asian Sex Workers Free. Sydney Morning Herald. April 4. Available online: https://www.smh.com.au/national/truth-and-visas-will-set-asian-sex-workers-free-20080404-gds80c. html (accessed on 31 August 2020).

Jung, Kyungja, and Yong Moon Jung. 2020. Neoliberal Migration Regime, Escape from 'Hell Joseon' and the Pursuit of Cosmopolitan Aspiration: An Overview of Temporary Migration from South Korea to Australia. International Review of Korean Studies 16: 41-68.

Kissane, Karen. 2008. Madam or Slave Owner? The Age. May 17. Available online: https://www.theage.com.au/ national/madam-or-slave-owner-20080517-ge735l.html (accessed on 31 August 2020).

Lainez, Nicolas. 2019. Social structure, relationships and reproduction in quasi-family networks: brokering circular migration of Vietnamese sex workers to Singapore. Journal of Ethnic and Migration Studies 45: 1631-49.

Lainez, Nicolas. 2020. Debt, trafficking and safe migration: The brokered mobility of Vietnamese sex workers to Singapore. Geoforum, March 10.

Lyneham, Samantha, Christopher Dowling, and Samantha Bricknell. 2019. Estimating the Dark Figure of Human Trafficking and Slavery Victimisation in Australia. Statistical Bulletin no. 16. Canberra: Australian Institute of Criminology.

Mai, Nicola. 2016. 'Too Much Suffering': Understanding the Interplay between Migration, Bounded Exploitation and Trafficking through Nigerian Sex Workers' Experiences. Sociological Research Online 21: 159-72. [CrossRef]

Mai, Nicola. 2018. Mobile Orientations: An Intimate Autoethnography of Migration, Sex Work, and Humanitarian Borders. London: University of Chicago Press.

Mai, Nicola, P. G. Macioti, Calum Bennachie, Annie E. Fehrenbacher, Calogero Giametta, Heidi Hoefinger, and Jennifer Musto. 2020. forthcoming. The Racialised Bordering Politics of Sexual Humanitarianism: Migration, Sex Work and Trafficking. Ethnic and Racial Studies. under review.

Mancuso, Marina. 2014. Not all madams have a central role: analysis of a Nigerian sex trafficking network. Trends in Organized Crime 17: 66-88.

McInnes, Dianne, and Paul Wilson. 2012. Sex Trafficking: The Dark Side of the Australian Sex Industry? Sydney: New Holland.

Marchant, Gabriella. 2019. Study Finds Half of Human Traffickers Are Women, and Many Have Been Victims. ABC News. April 21. Available online: https://www.abc.net.au/news/2019-04-12/research-finds-half-ofhuman-traffickers-in-australia-are-women/10997902 (accessed on 31 August 2020).

Mitchell, Neil. 2019. Massage Parlour Brothels Busted: One Shut DOWN Every Week. 3AW News Talk. November 21. Available online: https://www.3aw.com.au/massage-parlour-brothels-busted-one-shut-down-every-week/ (accessed on 31 August 2020).

Molland, Sverre. 2010. The value of bodies: Deception, helping and profiteering in human trafficking along the Thai-Lao Border. Asian Studies Review 34: 211-29. [CrossRef]

Munro, Vanessa E. 2005. A tale of two servitudes: Defining and implementing a domestic response to trafficking of women for prostitution in the UK and Australia. Social \& Legal Studies 14: 91-114.

Musto, Jennifer. 2016. Control and Protect: Collaboration, Carceral Protection, and Domestic Sex Trafficking in the United States. Berkley: University of California Press. 
O'Brien, Erin. 2017. Against the trend: Resistance to neo-abolitionism in Australian anti-trafficking policy debates. In Feminism, Prostitution and the State. The Politics of Neo-Abolitionism. London and New York: Routledge, pp. 121-39.

O'Brien, Erin. 2019. Challenging the Human Trafficking Narrative: Victims, Villains, and Heroes. London: Routledge.

Parliament of Australia, House of Representatives Committee. n.d. Appendix H-Summary of Convictions for Divisions 270 and 271 of the Criminal Code and Related Offences Prosecuted by the Commonwealth Department of Public Prosecutions. Available online: http://www.aph.gov.au/DocumentStore.ashx?id= ba112422-cd6e-43a0-a561-912de4ba5c64\&subId=510673 (accessed on 31 August 2020).

Parliament of New South Wales. 2017. Select Committee on Human Trafficking in NSW. Available online: https: //www.parliament.nsw.gov.au/committees/listofcommittees/Pages/committee-details.aspx?pk=250 (accessed on 10 October 2020).

Parliament of New South Wales. 2020. Signing E petition. Proclaim the NSW Modern Slavery Act 2018 Now. Available online: https://www.parliament.nsw.gov.au/la/Pages/ePetition-details.aspx?q=Ta3SifrkU/ SgnMNzTLsUZw==\&mc_cid=cd493bf143\&mc_eid=6fabf9af9e (accessed on 31 August 2020).

Plambech, Sine. 2017. Sex, deportation and rescue: Economies of migration among Nigerian sex workers. Feminist Economics 23: 134-59. [CrossRef]

Project Respect. 2017. Position Statement: Illegal Brothels. Available online: https://d3n8a8pro7vhmx. cloudfront.net/projectrespect/pages/15/attachments/original/1504666071/01062017_Position_Statement_ Illegal_Brothels_-_FINAL.pdf?1504666071 (accessed on 31 August 2020).

Red Cross. 2019. Support for Trafficked People Program. Data Snapshot: 2009 to 2019. Available online: https://www.redcross.org.au/getmedia/7a957782-a7a1-4b25-97c0-86930dbf0f53/ARC-Support-ForTrafficked-People-Program-Data-Snapshot-2009-to-2019-small.pdf.aspx (accessed on 31 August 2020).

Renshaw, Lauren, Jules Kim, Janelle Fawkes, and Elena Jeffreys. 2015. Migrant Sex Workers in Australia. Research and Public Policy Series 131; Canberra: Australian Institute of Criminology, p. xii.

Roberts, Laura, and Jaqueline Breen. 2019. NT Decriminalises Sex Work as Attorney-General Natasha Fyles Pushes through Change. ABC News. Available online: https:/www.abc.net.au/news/2019-11-26/northernterritory-sex-industry-bill-passed/11739820 (accessed on 31 August 2020).

Segrave, Marie, Sanja Milivojevic, and Sharon Pickering. 2017. Sex Trafficking and Modern Slavery: The Absence of Evidence. London: Routledge.

Selvey, Linda A., Roanna C. Lobo, Kahlia L. McCausland, Basil Donovan, Julie Bates, and Jonathan Hallett. 2018. Challenges facing asian sex workers in Western Australia: implications for health promotion and support services. Frontiers in Public Health 6: 171. [PubMed]

Simmons, Frances, Brynn O’Brien, Fiona David, and Laura Beacroft. 2013. Available online: https://www.aic.gov. au/publications/tandi/tandi464 (accessed on 10 October 2020).

Sodsai, Parisuth. 2019. The Majority of Illegal Brothels Are Massage Shops' Say Police. SBS Thai. October 3. Available online: https://www.sbs.com.au/language/english/the-majority-of-illegal-brothels-are-massageshops-say-police (accessed on 31 August 2020).

Spinks, Harriet. 2016. Overseas Student: Immigration Policy Changes 1995-2015. Parliamentary Library. Australian Parliament. Research Paper Series 2015-2016. Available online: https://www.aph.gov.au/About_ Parliament/Parliamentary_Departments/Parliamentary_Library/pubs/rp/rp1516/OverseasStudents (accessed on 31 August 2020).

Theeravit, Nitthat, Suphāng Čhanthawānit, Samān Laodamrongchai, Aungkana Kamopetch, Prēmčhai Wangsiriphaisān, Pairin Makjaroen, and Pattarin Kaochan. 2010. Understanding Recruitment Industry in

Thailand. Bangkok: Asian Research Centre for Migration, Institute of Asian Studies, Chulalongkorn University.

Ward, Eilís, and Gillian Wylie, eds. 2017. Feminism, Prostitution and the State: The Politics of Neo-Abolitionism. London: Taylor \& Francis.

Publisher's Note: MDPI stays neutral with regard to jurisdictional claims in published maps and institutional affiliations.

(C) 2020 by the authors. Licensee MDPI, Basel, Switzerland. This article is an open access article distributed under the terms and conditions of the Creative Commons Attribution (CC BY) license (http://creativecommons.org/licenses/by/4.0/). 